\title{
Herbal medicines and veno-occlusive disease in India
}

\author{
D. V. DATTA \\ M.D., Ph.D. \\ M. S. KHUROO \\ M.D. \\ A. R. Mattocks* \\ Ph.D. \\ B. K. Aikat \\ M.D. \\ P. N. ChHuttani \\ MD.
}

Division of Hepatic Diseases, Postgraduate Institute of Medical Education and Research, Chandigarh-160012, India

\section{Summary}

Six cases are described of veno-occlusive disease (VOD) after medicinal herb ingestion. The herb Heliotropium eichwaldii, taken by three patients, was found to contain the toxic pyrrolizidine alkaloid, heliotrine. Two patients presented with fulminant hepatic failure while the other four patients had a clinical picture suggestive of decompensated cirrhosis. The medical use of this herb may possibly be responsible for a significant proportion of acute and chronic liver disease in India, making it of public health importance.

\section{Introduction}

Medicinal herbs are widely used for various ailments throughout the world (Kiritikar, Basu and An, 1936; Chopra and Chopra, 1955; Watt and Breyer-Brandwijk, 1962; Schoental, 1968). Many of these plants contain pyrrolizidine alkaloids which are hepatotoxic.

Crotalaria poisoning is an important cause of childhood cirrhosis in Jamaica (Bras, Brooks and Walter, 1961). There is a paucity of reports about the role of herbal medicines in the aetiology of liver diseases from other countries (McLean, 1970). From India, only two cases of possible venoocclusive disease have previously been reported after ingestion of an unknown herb (Gupta, Gupta and Sharma, 1963). The present paper records six patients with hepatic veno-occlusive disease.

\section{Clinical observations}

During the period 1974-1977, six cases of hepatic veno-occlusive disease were diagnosed. The reason for herb intake, its nature and duration of intake are shown in Table 1. Three patients had taken the same herb, Heliotropium eichwaldii ('hathisunda'). It contained a highly toxic pyrrolizidine alkaloid, heliotrine. The concentration of heliotrine in the plant was $2 \%$ by weight (cases 1 and 2 ) and $1.2 \%$ (case 5) and the alkaloid was totally in the form of $\mathrm{N}$-oxides. The other three patients had a history of similar

TABLE 1. The various features of herbal medicines

\begin{tabular}{|c|c|c|c|c|c|}
\hline $\begin{array}{l}\text { Patient } \\
\text { No. }\end{array}$ & $\begin{array}{l}\text { Reason for } \\
\text { herb intake }\end{array}$ & $\begin{array}{l}\text { Nature } \\
\text { of herb }\end{array}$ & $\begin{array}{c}\text { Duration } \\
\text { of intake } \\
\text { (days) }\end{array}$ & $\begin{array}{c}\text { Time-lag } \\
\text { before onset } \\
\text { of symptoms } \\
\text { (days) }\end{array}$ & $\begin{array}{l}\text { Approximate } \\
\text { quantity of } \\
\text { heliotrine } \\
\text { taken/day } \\
\text { (mg) }\end{array}$ \\
\hline 1 & Epilepsy & $\begin{array}{l}\text { Heliotropium } \\
\text { eichwaldii }\end{array}$ & 20 & 45 & 200 \\
\hline 2 & Epilepsy & H. eichwaldii* & 50 & 90 & 200 \\
\hline 3 & Not known & - & - & 5 & \\
\hline 4 & Vitiligo & - & 50 & - & \\
\hline 5 & Vitiligo & H. eichwaldii $\dagger$ & - & 10 & 500 \\
\hline 6 & Diabetes & - & 30 & 45 & \\
\hline
\end{tabular}

*MRC Toxicology Unit, Medical Research Council Laboratories, Woodmansterne Road, Carshalton, Surrey SM5 4EF. 
TABLE 2. The clinical features of the six patients with veno-occlusive disease

\begin{tabular}{|c|c|c|c|c|c|c|c|c|c|c|}
\hline $\begin{array}{c}\text { Patient } \\
\text { No. }\end{array}$ & Onset & $\underset{\text { pain }}{\text { Abdominal }}$ & First symptom & Jaundice & $\begin{array}{l}\text { Hepato- } \\
\text { megaly }\end{array}$ & $\begin{array}{l}\text { Spleno- } \\
\text { megaly }\end{array}$ & Ascites & $\begin{array}{l}\text { Hepatic } \\
\text { coma }\end{array}$ & $\begin{array}{c}\text { Gastro- } \\
\text { intestinal } \\
\text { bleeding }\end{array}$ & Outcome \\
\hline 1 & Sudden & $\ldots$ & $\begin{array}{l}\text { Jaundice, abdominal } \\
\text { distension, coma }\end{array}$ & ++ & - & - & ++ & + & + & D \\
\hline 2 & Sudden & + & Jaundice, coma & +++ & $\begin{array}{l}6 \mathrm{~cm} \\
\mathrm{BCM}\end{array}$ & 一 & + & + & + & D \\
\hline 3 & Gradual & - & Abdominal distension & - & - & - & +++ & $+e$ & + & D \\
\hline 4 & Gradual & 一 & Abdominal distension & - & $\begin{array}{l}1 \mathrm{~cm} \\
\mathrm{BCM}\end{array}$ & $\begin{array}{l}2 \mathrm{~cm} \\
\mathbf{B C M}\end{array}$ & + & - & - & n.k. \\
\hline 5 & Gradual & 一 & Abdominal distension & + & $\begin{array}{l}3 \mathrm{~cm} \\
\mathrm{BCM}\end{array}$ & - & ++ & - & - & n.k. \\
\hline 6 & Gradual & - & Painful abdomen & - & $\begin{array}{l}7 \mathrm{~cm} \\
\mathrm{BCM}\end{array}$ & $\begin{array}{l}1 \mathrm{~cm} \\
\mathrm{BCM}\end{array}$ & - & - & - & $\mathbf{L}$ \\
\hline
\end{tabular}

BCM - Enlargement of the viscera below costal margin; e - as a terminal event ; + - present ; - absent ; D - died; L - living; n.k. - not known.

herbal medicine use, but the exact nature of the plant could not be confirmed.

All the six patients posed considerable problems of diagnosis. None of the patients connected his present illness with ingestion of a herb. Two patients (cases 1 and 2) presented with fulminant hepatic failure characterized by sudden onset of jaundice, abdominal pain, ascites, gastrointestinal bleeding and hepatic encephalopathy (Table 2). Death occurred within 12 weeks (case 2) and in the 2nd week (case 1) of the hospital course. The liver function test suggested evidence of active hepatocellular necrosis (Table 3). Viral hepatitis was the diagnosis considered in both patients during life. Three patients (cases 3, 4 and 5) presented with an insidious onset of abdominal distension, with or without hepatosplenomegaly (Table 2 ). The sixth patient presented with abdominal pain and hepatosplenomegaly and had no ascites. Cirrhosis of the liver was the diagnosis considered in patients 3-6. Liver function tests in these patients showed evidence of chronic liver cell dysfunction. The three subjects who died (cases 1,2 and 3) were examined post mortem. All showed the same pattern of changes in various stages of evolution. The inferior vena cava and major hepatic veins were patent. The main changes were centrilobular haemorrhagic necrosis, sinusoidal dilatation, with minimal cellular infiltration, collapse of the reticulin, bridging and reversed lobulation (Figs 1 and 2). Central and sublobular veins showed occlusion with subendothelial collagen tissue and areas of recanalization (Fig. 3). The changes were patchy. The liver biopsies of cases 4,5 and 6 showed centrilobular haemorrhagic necrosis with reticulin collapse. Typical changes in the central veins were seen in two patients (cases 4 and 5). In case number 6 the site of outflow block was found by haemodynamic studies to be located at the smallest hepatic veins. The major hepatic veins and inferior vena cava were patent.

TABLE 3. Investigations on six patients with veno-occlusive disease

\begin{tabular}{|c|c|c|c|c|c|c|c|c|c|c|c|}
\hline $\begin{array}{l}\text { Patient } \\
\text { No. }\end{array}$ & $\underset{(\mathrm{g} / \mathrm{dl})}{\mathrm{Hb}}$ & PCV & $\begin{array}{c}\text { Serum } \\
\text { bilirubin } \\
(\mu \mathrm{mol} / \mathrm{l})\end{array}$ & $\begin{array}{l}\text { Serum } \\
\text { albumin } \\
(\mathrm{g} / \mathrm{l})\end{array}$ & $\begin{array}{l}\text { Serum } \\
\text { globulin } \\
(\mathrm{g} / \mathrm{l})\end{array}$ & $\begin{array}{l}\text { SGOT } \\
\text { (i.u.) }\end{array}$ & $\begin{array}{l}\text { SGPT } \\
\text { (i.u.) }\end{array}$ & $\begin{array}{c}\text { Alkaline } \\
\text { phosphate } \\
\text { (i.u./l) }\end{array}$ & $\begin{array}{c}\text { Prothrombin } \\
\text { index } \\
(\%)\end{array}$ & $\begin{array}{l}\text { Ascitic } \\
\text { fluid } \\
\text { protein } \\
\text { content } \\
\quad(g / l)\end{array}$ & $\begin{array}{c}\text { Oesophageal } \\
\text { varices }\end{array}$ \\
\hline 1 & $12 \cdot 6$ & $0 \cdot 37$ & 547 & 21 & 24 & 60 & 37 & 128 & 27 & 20 & No \\
\hline 2 & 19 & 0.52 & $256-428$ & 33 & 45 & 87 & 72 & 91 & 28 & 21 & + \\
\hline 3 & 16 & 0.48 & $8 \cdot 5$ & 15 & 28 & 5 & 6 & 40 & 56 & 6 & + \\
\hline 4 & 6 & - & $8 \cdot 5$ & 18 & 24 & 7 & 8 & 21 & 59 & 12 & No \\
\hline 5 & 17 & 0.52 & $8 \cdot 5$ & 28 & 17 & 37 & 24 & 94 & .74 & 10 & - \\
\hline 6 & $10 \cdot 4$ & 0.35 & $8 \cdot 5$ & 28 & 41 & 29 & 10 & 432 & 100 & - & + \\
\hline
\end{tabular}

- absent; + - present. 


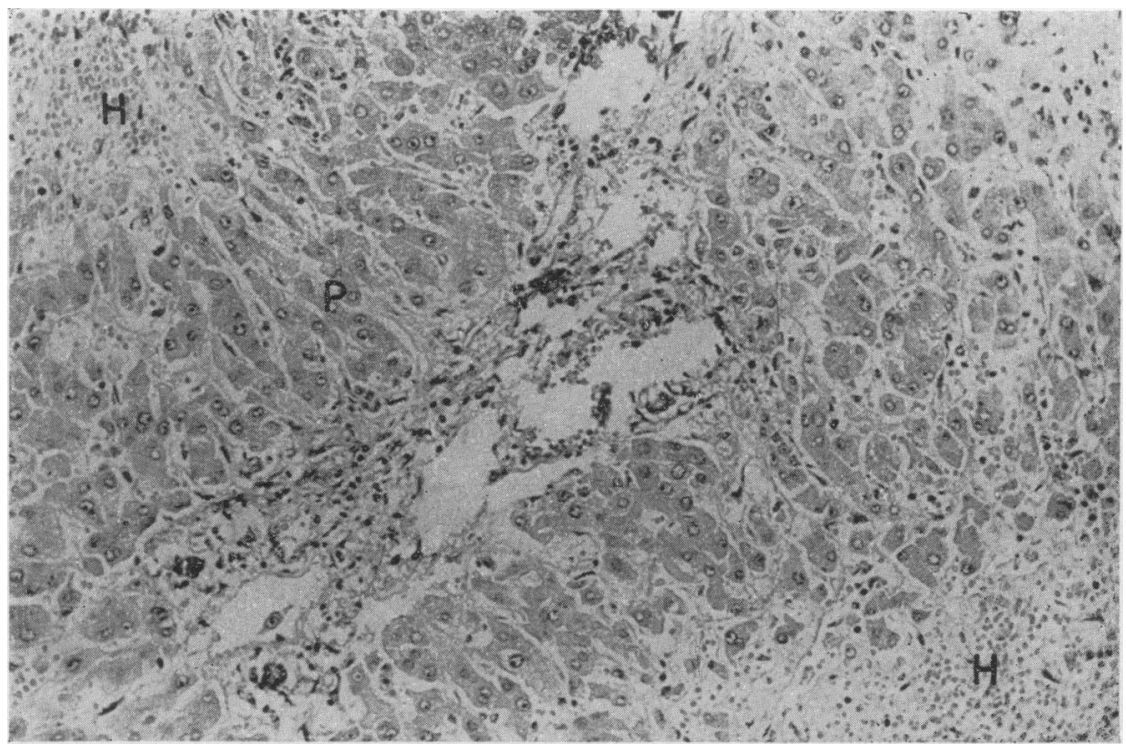

Fig. 1. Case 1. Microphotograph of liver showing surviving periportal liver cells (P) with dilatation of sinusoids. Haemorrhages and complete disappearance of liver cells is seen further out $(\mathrm{H})$ around centrilobular areas. Minimal portal and lobular inflammation is seen. $(\mathrm{HE}, 40 \times 10$.)

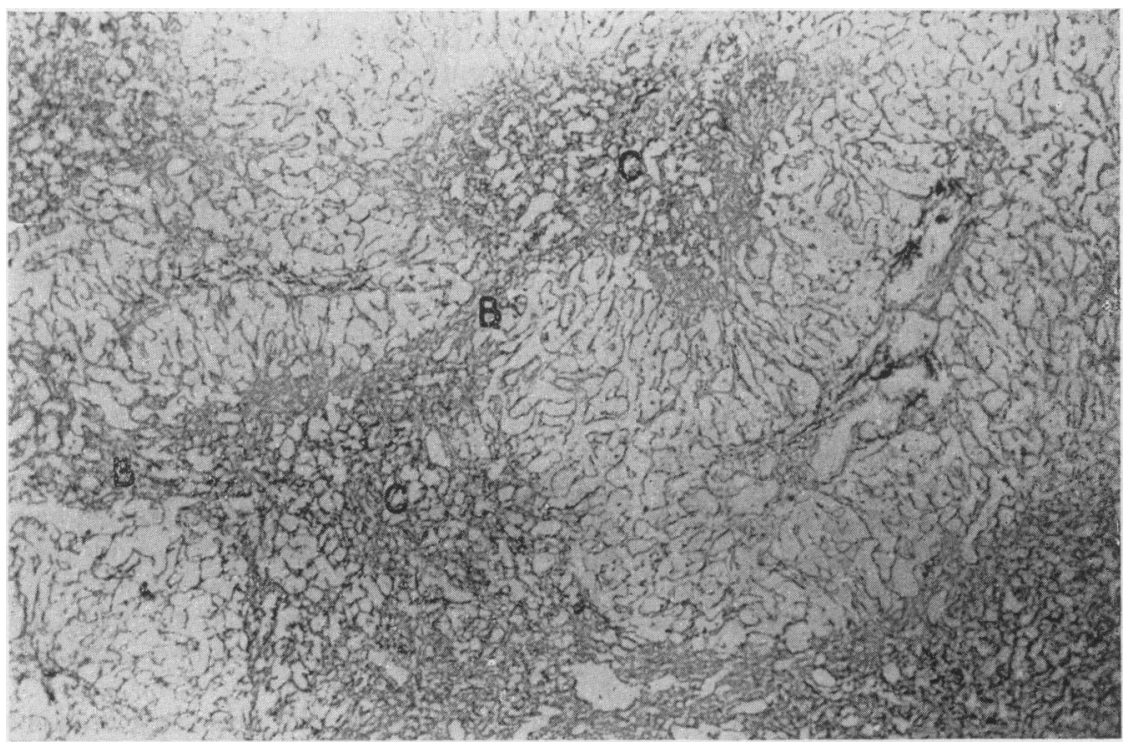

Fig. 2. Case 1. Microphotograph of liver showing massive centrilobular collapse of reticulin (C) with bridging (B) and pseudo-lobule formation. Periportal reticulin is sparse.

(Reticulin stain, $40 \times 10$.) 


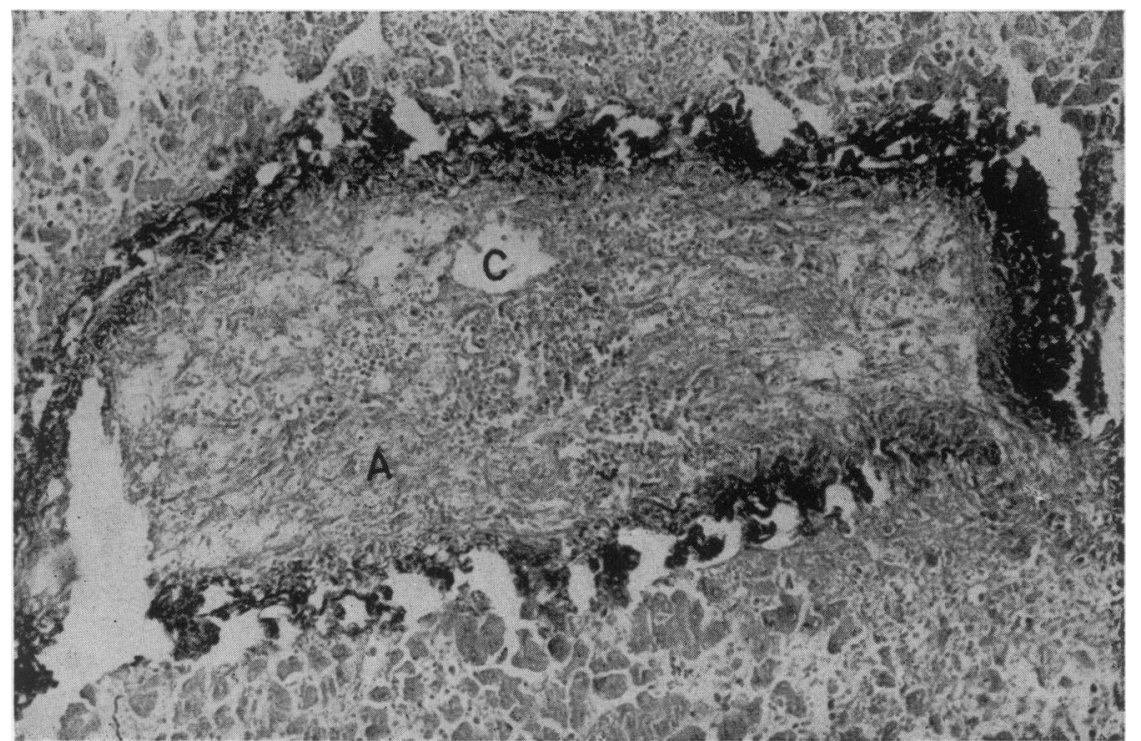

Fig. 3. Case 1. Microphotograph of liver showing sublobular vein with complete occlusion by oedematous connective tissue (A). Area of recanalization is seen (C). (HE, $40 \times 10$.)

\section{Discussion}

The pyrrolizidine alkaloids have become increasingly interesting owing to their toxic action (McLean, 1970). Plants containing them are an important veterinary hazard in some countries, especially during shortage of pasture (McLean, 1970). Poisoning in man has occurred by contamination of cereals, leading to epidemics of venoocclusive disease (Selzer and Parker, 1951; Braginskii and Bobokhodzhaev, 1965; Tandon et al., 1976; Mohabbat et al., 1976; Koshy et al., 1976). The use of these plants as herbal medicines is yet another important, and difficult to detect, source of hazard to man (Bras et al., 1961; McGee et al., 1976; Hyford, Vergara and Moeller, 1976).

Herbal treatment is a common form of therapy in many countries (Kiritikar et al., 1936; Chopra and Chopra, 1955; Watt and Breyer-Brandwijk, 1962; Schoental, 1968). Although primarily adopted by the rural population, even urban dwellers accept it when faced with chronic or incurable illness. The therapeutic roles of various Heliotropium species are highlighted in Indian traditional medicine (Ayurvedism) (Schoental, 1968). H. eichwaldii is used for the treatment of many common ailments in India, including intractable fever, local fever, inflammations, wounds, and also as a diuretic (Kiritikar et al., 1936; Chopra and Chopra, 1955). The plant has been studied for its alkaloids (Gandhi, Rajagopalan and
Seshadri, 1966; Suri, Sawhney and Atal, 1597). However, there do not appear to be any previous recorded cases of human poisoning with this herb.

Veno-occlusive disease constitutes about $30 \%$ of liver cirrhosis in Jamaica (McLean, 1970). What percentage of cirrhosis in India could be due to chronic veno-occlusive disease is a question which cannot be answered at present. Veno occlusive disease has not been incriminated in the aetiology of liver cirrhosis in any of the previous Indian studies (Ramalingaswami, Wig and Sama, 1962; Aikat, Bhattacharya and Walia, 1974; Aikat et al., 1975). However, the recognition of six cases in a short period of time suggests the possibility that Heliotropium toxicosis may comprise a significant proportion of acute and chronic liver disease in India. A history of herb ingestion is not routinely elicited since patients do not normally associate their illness with herb intake, and the time-lag between stopping the treatment and the onset of illness causes difficulties in diagnosis. Moreover, the clinical picture of the disease is varied and may simulate common illnesses such as viral hepatitis and cirrhosis. To make a diagnosis, liver biopsy is necessary. This may be difficult during life because of massive ascites and coagulation disorders. This happened with three patients in the present study. Ultimately, postmortem may be the only definite way to confirm the diagnosis. 
Jaundice has been thought to be characteristically absent or minimal in VOD and, if present, occurs late in the course of the illness. Two patients in the present study started with a history of deep jaundice. The possibility of another toxin, such as aflatoxin, being the cause of deep jaundice and outflow obstruction was considered in these patients. However, in both of them, samples of the herbal medicines were shown to contain toxic alkaloids and the diagnosis was confirmed at post-mortem. Features of toxic liver injury, as described in an epidemic from North West India (Tandon et al., 1977) were lacking.

The authors believe that VOD might be detected if it is considered in any obscure acute or chronic liver disease. A history of herbal treatment in the previous 3 months is most important in suspecting the disease. The clinical picture if characteristic may help. However, the disease can have a varied presentation. Liver function tests are not diagnostic, but biopsy, if possible during life, will show the characteristic pattern of hepatic outflow tract obstruction.

\section{References}

Aikat, B.K., Bhattacharya, T. \& Walia, B.N.S. (1974) Morphological features of Indian childhood cirrhosis. Indian Journal of Medical Research, 62, 953.

Aikat, B.K., Ghosh, R.N., Chhuttani, P.N. \& Datta, D.V. (1975) Morphological features and probable mode of evolution of cirrhosis of the liver in adults in north India. Indian Journal of Medical Research, 63, 1747.

Braginski, B.M. \& BoboKhodzhaEv, I.Ya (1965) Hepatolienal syndrome in heliotrope toxicosis. Soviet Medicine, 28, 57.

Bras, G.G., Brooks, S.E.H. \& Walter, D.C. (1961) Cirrhosis of the liver in Jamaica. Journal of Pathology and Bacteriology, 82, 503.

ChOPRA, R.N. \& ChOPRA, I.C. (1955) A review of the work on Indian Medical Plants (including indigenous drugs and poisonous plants). Indian Council of Medical Research, Special Report Series, New Delhi.
Gandhi, R.N., Rajagopalan, T. \& Seshadri, T.R. (1966) Components of Heliotropium eichwaldii. Current Science (India), 35, 121.

Gupta, P.S., Gupta, G.S. \& Sharma, M.L. (1963) Venoocclusive disease of liver. British Medical Journal, 1, 1184.

Hyford, C.L., Vergara, G.G. \& Moeller, D.D. (1976) Veno-occlusive disease originating in Ecuador. Gastroenterology, 70, 105.

KIRITIKAR, K.R., BASU, B.D. \& AN, I.C.S. (1936) Indian Medicinal Plants, 2nd edn, p. 1689. Allahabad.

Koshy, A., Narendran, M., Rajani, M., ManChanda, S.C., TANDON, H.D. \& TANDON, B.N. (1976) Veno-occlusive disease in Madhya Pradesh-Clinico-pathological profile. Paper read at 16th conference of the Indian Society of Gastroenterology, Indore.

McGee, J.O'D., Patrick, R.S., Wood, C.B. \& Blumgart, L.H. (1976) A case of veno-occlusive disease of the liver in Britain associated with herbal tea consumption. Journal of Clinical Pathology, 28, 788.

MCLEAN, E.K. (1970) The toxic actions of pyrrolizidine (Senecio) alkaloids. Pharmacological Reviews, 22, 429.

Mohabbat, S., SRIvastava, R.N., Younos, M.S., SediQ, G.G., Merzad, A.A. \& ArAM, G.N. (1976) An outbreak of veno-occlusive disease in North-western Afghanistan. Lancet, ii, 269.

Ramalingaswami, V., Wig, K.L. \& Sama, S.K. (1962) Cirrhosis of the liver in northern India-a clinicopathological study. Archives of Internal Medicine, 110, 350.

SCHOENTAL, R. (1968) Toxicology and carcinogenic action of pyrrolizidine alkaloids. Cancer Research, 28, 2237.

Selzer, G. \& Parker, R.G.F. (1951) Senecio poisoning exhibiting as Chiari's syndrome. American Journal of Pathology, 27, 885.

Suri, O.P., Sawhney, R.S. \& Atal, C.K. (1975) Pyrrolizidine alkaloids from Heliotropium eichwaldii and Lindelofia spectabilis. Indian Journal of Chemistry, 13, 505.

Tandon, B.N., Krishnamurthy, L., Koshy, A., Tandon, H.D., Ramalingaswami, V., Bhandari, J.R., MathuR, M.M. \& MATHUR, P.D. (1977) Study of an epidemic of jaundice presumably due to toxic hepatitis in North-West India. Gastroenterology, 72, 488.

Tandon, R.K., Tandon, B.N., Tandon, H.D., Bhatia, M.L., Bhargava, S., Lal, P. \& ARORA, R.R. (1976) A study of an epidemic of veno-occlusive disease in India. Gut, $17,849$.

WATt, J.M. \& Breyer-BrandwiJk, M.S. (1962) The Medicinal and Poisonous Plants of Southern Africa, 2nd edn. R. \& S. Livingstone, Edinburgh. 